6. Arutyunova N. Discourse and Metaphor. Theory metaphor [Collections of articles]. Ed. N.Arutyunova and M. Zhurynskaya. Moscow: Progress, 1990. P. 5-32.

7. Leychik V. Linguistic problems of terminology and the scientific-technical translation. Part II. M. 1990. 80 p.

8. Калькова Л. Ф. Левченко Н. В., Бабіна О. О. Украйнсько-російськоарабський тлумачний словник іншомовних термінів із дитячой терапевтичної стоматологї. Полтава: ВДНЗУ, 2017. $101 \mathrm{c.}$

9. Нідзельський М. Я., Писаренко О. А. Тлумачний термінологічний довідник із ортопедичної стомтології. Полтава: ВДНЗУ, 2014. 262 с.

10. Babbush C. A., Fehrenbach M. J., Emmons M., Nunez D. W. Mosby's Dental Dictionary. St. Louis, Missouri: Mosby, 2008. 823 c.

11.Dentistry Journal [Електронний pecypc] - Режим доступу: https://www.mdpi.com/journal/dentistry

УДК 81'22 (811.161.2+811.111): 81'37

DOI: $10.24144 / 2617-3921.2020 .18 .167-178$

Тетяна Сорока

кандидат філологічних наук, дочент

дочент кафедри англійської філології

Ізмайльський державний гуманітарний університет, orcid.org/0000-0002-7680-6604

м. Ізмаӥл, Україна, +38 (050) 190-32-79

magpie3f@mail.ru

\title{
Специфіка семного складу іменників на позначення моральності в сучасних українській та англійській мовах
}

Анотаиія. У статті досліджується семний склад іменників на позначення моральності в сучасних українській та англійській мовах із застосуванням матричного методу. Ідентифіковано вказівки на моральноетичні характеристики в лексикографічних тлумаченнях слів на позначення иінностей в двох мовах. Введено в науковий обіг терміни генералізована сема (ГС) та сема комбінованої функиіональності. Розрізнено ГС за типами їхньої функиіональності: багатофункиіональні, однофункціональні та семи комбінованої функціональності. Визначена здатність сем комбінованої функиіональності виступати компонентами лексичних значень слів на 
позначення иінностей водночас як з найвищим і середнім ступенем полісемії, так і моносемічних. Проаналізовано три типи генералізованих сем щодо їхньої передачі специфіки моральної свідомості $i$ моральної практики суб'єкта в лексичній семантиці досліджуваних аксіономенів. Розкрито діалектичний характер взаємодії моральної свідомості і моральної практики в семантичному просторі досліджуваних мов. Інтерпретація моральної свідомості і моральної практики мовними засобами двох мов потребувала групування словникового і семного складу в межах відповідних матриць. В українській матричі моральна свідомість описується багатофункиіональними ГС: “позитивна риса, якість", "почуття прихильності, доброзичливості”, "втілення чесності, порядності”, “те(ті), що(чим)...”, “гідність”, “моральні принципи, переконання”, “моральний ідеал, справедливість”, “невинність, цнотливість”, “добре ім'я”, "репутація, авторитет”, "поважність" та однофункиіональними ГС: “почуття жалю”, “сумління”, “теплі, ніжні почуття”, “почуття подяки”. B англійській матрииі моральна свідомість описується багатофункиіональними ГС "virginity; celibacy", "righteousness", "reputation, standing", "freedom (from)" та однофункиіональною ГС "ридепсу”. Для розкриття сутності моральної практики використано українські багатофункиіональні ГС “ставлення”, “стосунки, відносини”, “зовнішній вияв поваги”, “добрі вчинки, наслідки, результати”, “норми поведінки”, “на честь", “увага", “глибока приязнь”, “чулість”, “вияв жсалості", “людинолюбство”, “турбота", "безкорисливе піклування, нагляд” та однофункиіональні ГС “помилування”, “привітність”, “ласка”, “любов до Батьківщини, народу”, “відданість”, “готовність віддячити”, “гостинне приймання”, “героїчні подвиги”. Моральна практика інтерпретована англійськими багатофункціональними ГС "adherence, allegiance", "favour", "kindness", "regard, esteem", "fairness, frankness", "obligation", "correctness", "propriety, decorum", "leniency", "care", "nobility; magnanimity", "aid", "interest(s), concern", "ability, capacity", "conduct", "way (of), manner (of), method", "veracity", "simplicity", "restraint", "attitude(s)" ma однофункиіональною ГС "seriousness". На матеріалі украӥнської мови виділено ГС комбінованої функиіональності - "властивість/якість за значенням" та "абстрактний іменник до...”. Англійські ГС комбінованої функиіональності "quality of", "act (of), action(s)", "feeling (of)", "agreement, conformity” встановлено в семантичній структурі аксіономенів.

Ключові слова: матричя, аксіономен, моральність, генералізована сема, багатофункиіональні семи, однофункціональні семи, семи комбінованої функиіональності.

Abstract. The purpose of the article is to study mental and ethical aspect of the Ukrainian and English axionomens' semantization. The terms "generalized seme" (GS) and "seme of combined functionality" were introduced into scientific 
circulation. Special attention to the indications of mental and ethical characteristics in lexicographical axionomens explanations and forms of their systematization due to definite generalized semes has been paid. The usage of multifunctional semes, single-functional semes and generalized semes of combined functionality which actualize specifics of axionomens' lexical semantics has been justified. The ability of generalized semes of combined functionality to act as components of lexical meanings of words denoting values with the high, middle degree of polysemy and monosemantic ones is determined. Three types of generalized semes are defined as factors of nuancing moral consciousness and moral practice of a human being. The dialectical nature of the interaction of moral consciousness and moral practice in the semantic space of the studied languages is revealed. Interpretation of moral consciousness and moral practice by the linguistic means of two languages required grouping vocabulary and semantic structure within the appropriate matrices. In the Ukrainian matrix, moral consciousness have been presented with multifunctional GSs "позитивна риса, якість", "почуття прихильності, доброзичливості", "втілення чесності, порядності", “те(ті), що (им)...”, “гідність”, “моральні принципи, переконання”, “моральний ідеал, справедливість”, “невинність, ичнотливість", “добре ім'я”, “репутаиія, авторитет”, “поважність” and single-functional semes "почуття жалю”, “сумління", "теплі, ніжні почуття", "почуття подяки". In the English matrix, moral consciousness have been described with multifunctional GSs "virginity; celibacy", "righteousness", "reputation, standing", "freedom (from)" and a single-functional seme "pudency".

The Ukrainian multifunctional GSs "ставлення", "стосунки, відносини”, "зовнішній вияв поваги”, "добрі вчинки, наслідки, результати”, "норми поведінки”, “на честь”, “увага”, “глибока приязнь”, "чулість”, “вияв жалості”, “людинолюбство”, “турбота”, “безкорисливе піклування, нагляд” and single-functional semes "помилування”, "привітність”, “ласка”, “любов до Батьківщчини, народу”, “відданість”, “готовність віддячити”, “гостинне приймання", "героӥчні подвиги" have been used to reveal the essence of moral practice. Moral practice has been interpreted with the English multifunctional GSs "adherence, allegiance", "favour", "kindness", "regard, esteem", "fairness, frankness", "obligation", "correctness", "propriety, decorum", "leniency", "care", "nobility; magnanimity", "aid", "interest(s), concern", "ability, capacity", "conduct", "way (of), manner (of), method", "veracity", "simplicity", "restraint", "attitude(s)" and a single-functional seme "seriousness". On the material of the Ukrainian language two generalized semes of combined functionality “властивість/якість за значенням", “абстрактний іменник до...” have been singled out. Four English generalized semes of combined functionality "quality of", "act (of), action(s)", "feeling (of)", "agreement, conformity" have been established in the semantic structure of axionomes.

Keywords: matrix, axionomen, morality, generalized seme, multifunctional semes, single-functional semes, semes of combined functionality. 
Вступ. Мовна об'єктивація категорії моралі як однією з форм суспільної свідомості, різновида відносин між людьми і засобу нормативної регуляції їхніх дій в соціумі представляє значний інтерес для лінгвістичного

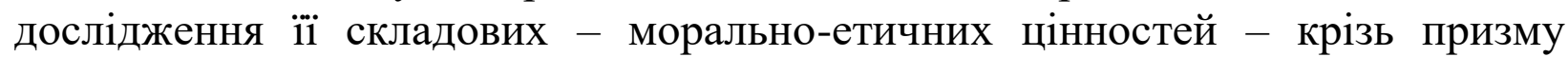
розкриття семантичного змісту аксіономенів ${ }^{1}$. У звязку 3 цим необхідність вирішення питання про характер співвідношень аксіономенів різного ступеню полісемії, які своїми лексичними значеннями розкривають сутність моральності українсько- та англомовних спільнот, зумовлює актуальність заявленої проблематики.

Методологія та методи дослідження. Загальнонауковим підгрунтям роботи $€$ принцип антропоцентризму, осмислений в проекції на етноцентризм. У дослідженні застосовано загальнонаукові методи (аналіз, синтез, індукція і дедукція), які доповнено спеціальними лінгвістичними методами. Так, аналіз лексикографічних джерел сприяв збору мовного матеріалу дослідження, а дефініційний аналіз допоміг у вивченні лексичних значень іменників на позначення цінностей, що відображено в їхніх словникових тлумаченнях, методика компонентного аналізу слугувала для розкриття семантичної структури аксіономенів й виділення їхнього семного складу в досліджуваних мовах.

У низці статей, присвячених аналізу лексико-семантичної структури слів на позначення духовних цінностей $[7 ; 8 ; 9]$, викладено результати наукового дослідження виключно англомовних аксіономенів 3 найвищим і середнім ступенем полісемії, які кваліфікуються як ціннісно-обумовлені реєстрові одиниці лексикографічних джерел тлумачного характеру [13; 14]. Тому охоплення всього спектру семантичних зв'язків між полі- і моносемантичними аксіономенами двох неспоріднених мовах в аспекті синхронійної передачі смислової структури їхніх словникових тлумачень видається доцільним.

Мета дослідження полягає в полягає в розкритті морально-етичного компонента змісту семантичної структури українсько- та англомовних аксіономенів із застосуванням матричного методу. Досягнення мети передбачає розв'язання таких завдань: 1) ідентифікувати вказівки на морально-етичні характеристики в лексикографічних тлумаченнях слів на позначення цінностей в двох мовах; 2) проаналізувати багатофункціональні, однофункціональні та генералізовані семи комбінованої функціональності, що передають специфіку моральної свідомості і моральної практики в лексичній семантиці досліджуваних аксіономенів.

Виклад основного матеріалу дослідження. При аналізі моралі як цілісної системи, $з$ точки зору В. А. Малахова, необхідно розглядати іiі структурні елементи: моральну свідомість, моральну діяльність та моральні відношення

1 Аксіономен (від грецького ásía - "цінність" і латинського - nomen - "ім’я, назва") є робочим терміном, упровадженим у науковий обіг автором для позначення філософськосвітоглядних, наукових, громадсько-політичних, соціальних, моральних, релігійних, правових і естетичних цінностей. 
[3, с. 103]. Але, враховуючи наведене, ми вважаємо за доцільне підтримати іншу позицію, згідно з якою останні два компоненти - моральна діяльність та моральні відношення - об'єднуються під загальною назвою моральна практика [2, с. 243], яка включає в себе всю сферу індивідуально-масових виявів моральної діяльності та відношень, орієнтованих на моральні принципи та норми. Моральна практика неодмінно пов'язана 3 моральною свідомістю, більш того, вони взаємопороджують та взаємообумовлюють один одного. 3 одного боку, як носії моральної свідомості «індивіди підносяться до моральної діяльності відповідно до вираженої в нормах міри людяності, яка існує для них у формі категоричного імперативу, регламентована моральними цінностями й принципами моральної свідомості» [1]; з іншого - моральна свідомість сама $€$ ідеальним відображенням і впорядкуванням моральної реальності, тобто моральної практики [3, с. 105].

До моральної свідомості прийнято відносити моральні принципи, моральні норми, моральні цінності. Стрижень моральної орієнтації людини складають моральні принципи, які $є$ тією підставою, що визначає вибір людиною того чи іншого варіанту поведінки, дотримання нею відповідних моральних норм. Саме ці принципи є базовими для інших елементів моральної свідомості; до них відносять гуманізм, альтруїзм, толерантність тощо. Усталені потреби людського співжиття та відносин відображаються у моральних нормах, які $\epsilon$ найпростішою формою моральних приписів; вони можуть носити характер як позитивних вимог, так і заборон. Змістом моральних норм є моральні цінності, які виступають чимось більшим од них. Норми, що не сповнені ціннісного смислу, можна вважати лише механічною сукупністю правил.

Морально-етичні цінності прийнято визначати як суспільні установки, імперативи, котрі виражені у формі нормативних уявлень про добро та зло, справедливе та несправедливе, про сенс життя та призначення людини тощо.

Крім того, їх розглядають як систему світорозуміння окремого індивіду, яка включає в себе оцінку всього існуючого 3 позицій добра та зла, що дозволяє встановити зв'язок між вчинком людини та загальноприйнятою системою соціальних цінностей [4].

Інтерпретація моральної свідомості і моральної практики мовними засобами двох мов потребує групування словникового і семного складу в межах відповідних матриць.

Аналізуючи семантику ціннісно-зумовленої лексики, що виражає моральність, зазначимо, що за матрицею, в якій достатньо повно представлено семантична значущість аксіономенів, уможливлюється вивчення їхніх співвідношень в межах лексико-семантичних угруповань. В порівнянні 3 тлумачним словником матриця формально простіше представляє лексичну семантику двох мов, а топографічний спосіб розміщення в ній заповнених клітин практично замінює словесне вираження тлумачної частини. 
За допомогою методу компонентного аналізу в семемах слів виокремлюються семи, під якими розуміємо елементарні, граничні одиниці семантичної системи мови. Вони можуть виступати мінімальними розрізнювальними рисами, об'єктивно притаманними як денотату, так i конотату лексичної одиниці $[5$, с. 23 ; 6 , с. $632 ; 10$, с. 8 ; 11, с. 187-188; 12, с. 66]. На позначення компонентів змісту семеми використовуються різноманітні терміни: маркер (Дж. Катц, Дж. Фодор), фігура (Л. Ельмслєв), диференизійна ознака (І. Арнольд), семантичний множник (Л. М. Васильєв, О. К. Жолковський), семантична ознака (Г. А. Уфімцева), семантичний примітив (Г. Вежбицька) та інші. Відповідно до фактичного матеріалу нашого дослідження, вважаємо за потрібне ввести в науковий обіг термін генералізована сема (ГС), під якою розуміємо конструкт рубрикового або підрубрикового словникового тлумачення зі скорочено-узагальненим змістом, що виводиться логічним шляхом із вихідної семеми i застосовується в моделюванні горизонтальної ланки матриці. ГС, виступаючи дискретними семантичними елементами семем, функціонують в якості формалізованих вказівок на наявність семантично-похідних компонентів (враховуючи відтінки лексичних значень на рівні ремарок і позначок) в структурі лексичного значення одного або кількох різногрупних аксіономенів на позначення моральності.

Розрізнюємо ГС за типами їхньої функціональності: багатофункціональні, однофункціональні та семи комбінованої функиіональності (термін наш - Т. В. Сорока), останні з яких визначаються в нашому дослідженні як такі, що здатні виступати компонентами лексичних значень слів на позначення цінностей водночас як 3 найвищим і середнім ступенем полісеміі, так і моносемічних.

В українській та англійській матрицях моральна свідомість описується наступними ГС, що містяться в лексичних значеннях аксіономенів.

Українські багатофункціональні ГС: "позитивна риса, якість" (честь $_{14}{ }^{2}, \quad$ достоӥнство $_{6}, \quad$ мужнність 6 , довершеність 5 , благородство доброчесність 4 , гідність 2 ); “почуття прихильності, доброзичливості" як емоційна настроєність (любов 12 , благоговіння 6 , співчуття 6 , симпатія 4 ,

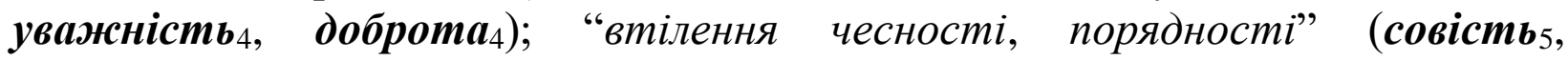
благородство $_{5}$, доброчесність 4 , чесність 3 , порядність 2$)$; " щзо(чим)..." (честь $14:$ "те, щуо дає право на шану, повагу, визнання", надія 4 : "те (той), на щуо (на кого) можна надіятися, покладатися, щуо (хто) $\epsilon$ відрадою, опорою для кого-небудь"); “гідність" (честь 14, гордість достоӥнство 6 ); “моральні принциипи, переконання" (честь 14 , совість 5 , мораль 5$)$; “моральний ідеал, справедливість" (правда, 9 , істина, справедливість 6 ); "невинність, цнотливість" (честь 14 , доброчесність 4 ); “добре ім'я" (честь 14: “чесне ім'я", слава 13 : "честь, добре ім'я”); “репутація, авторитет" (честь 14: “добра, незаплямована репутація, авторитет

\footnotetext{
${ }^{2}$ Тут і далі цифрою позначено загальна кількість лексичних значень аксіономена.
} 
людини", повага 7 : “діалектне слово. Авторитет"), авторитет 4 "поважність").

Англійські багатофункціональні ГС: невинність, непорочність, целібат ${ }^{3}$ за ГС "virginity; celibacy": жіноча цнотливість (honour 13 :“a woman's virtue"), virtue $_{9}$, chastity ch $_{7}$ у архаїчному значенні - невинність, цнотливість (honesty "Obsolete. virginity"); праведність за ГС “righteousness" (right ${ }_{21}$, morality $_{11}$, goodness $_{7}$, honesty 6 , rectitude 5 ); чиясь добра репутація за ГС "reputation, standing" (honour 13 : "somebody's good reputation"); відсутність мізерності, нікчемності в характері за ГС "freedom (from)" (generosity 6 : "freedom from pettiness in character").

Українські однофункціональні ГС: “почуття жалю" (співцутmя 6 ), "сумління" (совість 5$)$, “теплі, ніжні почуття" (симпатія 4 ), "почуття подяки" (вдячність 2$)$.

Англійська однофункціональна ГС на позначення сором'язливості (“pudency") виявлена в семантичній структурі лексеми modesty.

Для розкриття сутності моральної практики як якісної характеристики міжособистісної інтеракції в двох досліджуваних мовах встановлено діапазон ГС і тих аксіономенів, що складаються 3 них.

Українські багатофункціональні ГС: “ставлення" як характер

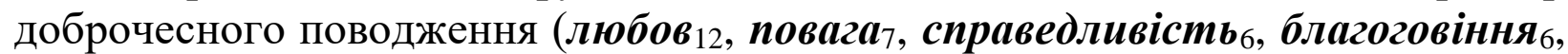

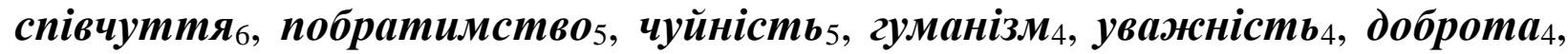
щцирість 3 , честь 14, милосердя 3 ); “стосунки, відносини” як добрі взаємини між людьми (любов 12, справедливість 6 , побратимство 5 , злагода 5 , дружба 4 , щุирістьз); “зовнішній вияв поваги” як вираження почуття шани (честь 14 , любов $_{12}$, повага 7 , благоговіння 6 , достоӥнство 6 ); “добрі вчинки, наслідки, результати" (добро 10, справедливість 6 , користь 3$)$; "норми поведінки" (порядок 17, мораль 5$)$; "на честь" (честь 14, пам'ять 9 , достоӥнство 6 ); "увага" (чуйність 5, уважність 4 , опікування 3 ); “глибока приязнь" (любов 12 , благоговіння 6 ); "чулість" (співчуття 6 , чуйність $)$; "вияв жалості" (співчуття 6 , милосердя 3 ); “людинолюбство” (гуманізм 4 , людяність 2 ); "турбота" (уважнність 4 , турботливість 2$)$; "безкорисливе піклування, нагляд" (опікування 3 , альтруїзм 2 ).

Англійські багатофункціональні ГС: прихильність, вірність, додержання приписів, правил за ГС “adherence, allegiance”: додержування моральних та правових принципів (right ${ }_{21}$ : "adherence to moral and legal principles"),

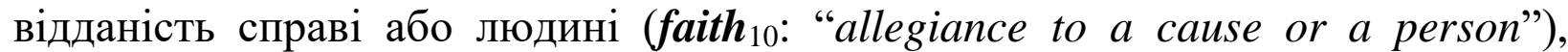
релігійне додержання морально-етичних принципів (integrity 7 : "adherence to moral and ethical principles"), додержання правових принципів (legality. “adherence to legal principles"), чесна відданість монарху, уряду, лідеру, справі тощо (loyalty : "faithful adherence to a sovereign, government, leader, cause, etc"),

${ }^{3}$ Тут і далі з метою полегшення читацького сприймання іншомовного тексту подано пояснення лексикографічних дефініцій аксіономенів. 
патріотична вірність; відданість (patriotism 2 : "adherence, allegiance"); прихильність, приязне ставлення до кого-, чого-небудь за ГС “favour": ласка,

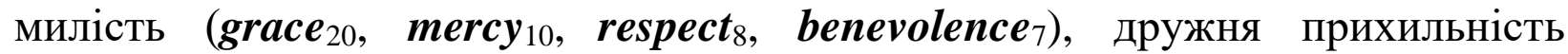
(friendship 6 , kindness 5 : "friendly favour"); доброзичливість за ГС "kindness"

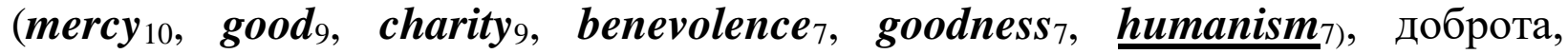
особливо у щедрому витрачанні речей (generosity 6 " "kindness to give things freely"); повага, шанування за ГС "regard, esteem" (honour 13 : "great respect, regard, esteem"), повага до батьків, вітчизни (piety 9 : "regard for parents, homeland", respect ${ }_{8}$, worship $_{8}$, duty $\left._{8}\right)$; відвертість, щирість за ГС "fairness, frankness": щирість, відкритість в спілкуванні (freedom 11 : "frankness in speech"), справедливість, законність (justice ${ }_{10}$ : “fairness"), чистота, чесність (integrity: "fairness"), щирість (honesty: "frankness"), відвертість; прямота (sincerity 4 : “frankness”); обов'язок, зобов'язання за ГС “obligation”: обов'язок, зобов'язання - лексичне значення в ірландському варіанті англійської мови (right 21 : “Irish. obligation"), відповідальність, обов'язок когось (trust , $_{12}$, duty 8 : "the obligation of someone"); коректність, правильність за ГС "correctness" (right $_{21}$, justice $\left.{ }_{10}\right)$; пристойність, етикет за ГС "propriety, decorum" (right ${ }_{21}$, decency $_{5}$, modesty $_{5} ;$ м'якість); поблажливість, лагідність, терпимість за ГС

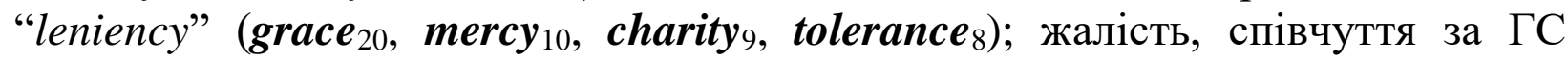
"compassion" (love ${ }_{17}$, sympathy $_{11}$, mercy $\left._{10}\right)$; піклування, уважність за ГС "care" (trust ${ }_{12}$ ); благородство, шляхетність за ГС "nobility; magnanimity" (dignity ${ }_{11}$, generosity $_{6}$ ); добровільна матеріальна допомога за ГС "aid" (charity 9 : "the voluntary giving of aid, typically in the form of money, to those in need"); турбота про людей за ГС “interest(s), concern" (humanism 7 : "concern for people"); здатність прощати людей за ГС “ability, capacity” (grace 20 : “a capacity to forgive people"); поведінка, що відповідає встановленим моральним стандартам за ГС "conduct" (morality ${ }_{11}:$ "conduct that is in accord with accepted moral standards"); спокійний, стриманий спосіб поводження за ГС “way (of), manner (of), method"

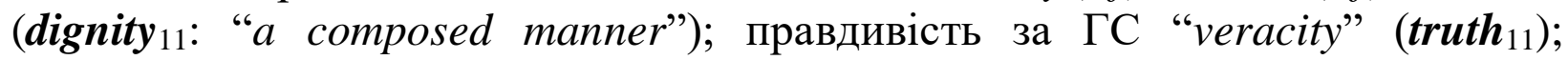
простота, скромність за ГС "simplicity" (chastity ${ }_{7}$, modesty $\left._{5}\right)$; стриманість за ГС "restraint" (стриманість у висловах: chastity 7 : "restraint in expression", moderation $_{5}$ ), самовладання всупереч спокусам чи бажанням (temperance 3 : "self-restraint in the face of temptation or desire"). ГС "attitude(s)" експлікує той чи інший характер поводження 3 ким-, чим-небудь, а саме: прихильне, доброзичливе ставлення (sympathy ${ }_{11}$ : "a favourable attitude", charity 9 : "a kindly and lenient attitude towards people", loyalty ${ }_{5}$ " "an attitude of devoted attachment"), шанобливість до батьків, до старших або родини (piety: “a pious attitude to parents, superiors, or family"), шанобливе ставлення, сповнене люб'язністю (respect 8 : "an attitude of consideration"), терпимість до чужого способу життя, поглядів, звичаїв, почуттів, раси, вірувань, національності (tolerance 8 : “ $a$ permissive attitude toward those whose opinions, practices, race, religion, nationality, etc., differ from one's own"), гуманність ( $\underline{\text { humanism }}_{7}$ : "human attitude"). 
Українські однофункціональні ГС: “помилування" (милосердя 3 ); "привітність", "ласка" (добротаа 4$)$; “любов до Батьківщини, народу", "відданість" (патріотизм 2$)$; “готовність віддячити" (вдячність 2$)$; “гостинне приймання” (гостинність $)$ ); “героїчні подвиги” (слава 13 : “доблесні діла, героїчні подвиги").

Англійська однофункціональна ГС: серйозність в поведінці, манерах за ГС "seriousness" (dignity 11 : "seriousness in behavior").

На матеріалі української мови виділяємо ГС комбінованої функціональності - “властивість/якість за значенням" та “абстрактний іменник до...".

ГС "властивість/якість за значенням відповідного прикметника" об'єднує як багатозначні справедливість 6 (“властивість за значенням справедливий), толерантність (“властивість за значенням толерантний”), доброчесність 4 (“властивість за значенням доброчесний"), щирість 3 (“властивість за значенням щирий”), чесністьз (“властивість за значенням чесний”), вихованістьз (“властивість за значенням вихований”), гостинність 3 ("властивість за значенням гостинний), порядність (“властивість за значенням порядний), дисциплінованість (“властивість за значенням дисциплінований), турботливість 2 (“властивість за значенням турботливий"), так і однозначні аксіономени ввічливість 1 (“властивість за значенням ввічливий”), тречність (“властивість за значенням тречний”),

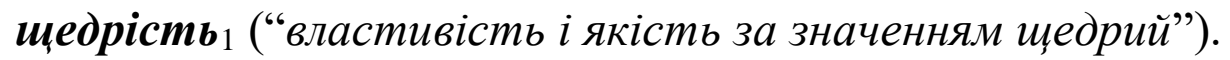

ГС “абстрактний іменник до відповідного прикметника" в словах із середнім ступенем полісемії займає перше місце в переліку лексичних значень: людяність 2 (“абстрактний іменник до людяний”), пристойність 3 (“абстрактний іменник до пристойний”). В моносемантах зазначена ГС виступає єдиним конституентом семантичної структури слів лояльність 1 ("абстрактний іменник до лояльний") і неупередженість 1 ("абстрактний іменник до неупереджений”).

Англійські ГС комбінованої функціональності - “quality of”, “act (of), action(s)", "feeling (of)", "agreement, conformity" - знаходимо в семантичній структурі слів з найвищим, середнім ступенем полісемії та моносемантичних аксіономенів. Так, вказівка на моральну якість за значенням відповідного прикметника (“quality of”) $\epsilon$ спільною для семантики мовних одиниць і характеризує здатність бути коректним (right ${ }_{21}$ : “the quality of being correct”), позитивні моральні якості, гідність (dignity ${ }_{11}$ : "the quality of being morally or

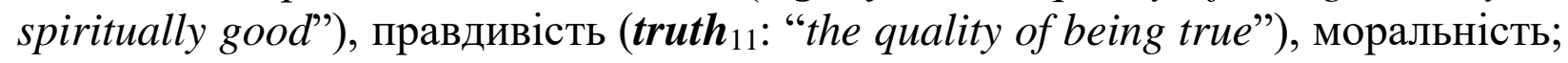
мораль (morality ${ }_{11}$ : "the quality of being moral"), справедливість (justice ${ }_{10}$ : "the quality of being just"), благочестя (piety 9 : "the quality of being pious"), доброчесність (virtue 9 : "the quality of being morally good"), толерантність (tolerance ${ }_{8}:$ "the quality of being tolerant"), чесність (integrity 7 : "the quality of being honest"), цнотливість (chastity ${ }_{7}$ " "the quality of being pure or chaste"), доброзичливість (benevolence 7 : "the quality of being well meaning"), доброту 
(goodness 7 : "the quality of being good"), чесність, правдивість (honesty 6 : "the quality of being fair, truthful"), доброту, великодушність (generosity 6 : "the quality of being kind and generous", kindness: "the quality of being kind"), порядність (decency $y_{5}$ " "the quality of being decent"), чесність, прямоту (rectitude 5 : "the quality of being straight"), вірність, відданість (loyalty: "the quality of being loyal"), скромність (modesty: "the quality of being modest"), відвертість (sincerity: "the quality of being open and truthful"), безсторонність, неупередженість (impartiality 1 : "the quality of not being prejudiced").

ГC “act (of), action(s)", зустрічаючись у лексичних значеннях аксіономенів, уточнює моральну дієвість через вияв доброти, жалю, помилування або не суворе ставлення до когось особливо з боку того, хто може карати за провину (mercy ${ }_{10}$ : "an act of kindness, compassion; the act of forgiving someone or not treating them severely, especially someone who you have the authority to punish"), щиросердечну дію (piety 9: “a devout act”), благодійність (charity 9 : "a charitable act"), акт прояву доброзичливості (benevolence 7 : “an act showing good will"), шляхетне обходження 3 ким-небудь (generosity: "a generous act"), добрий вчинок (kindness 5 : “a kind act”), ввічливість, чемність, гречність по відношенню до інших (politeness 1 : "the act of showing regard for others").

ГC “feeling (of)" репрезентує психічні й фізичні відчуття людини, стани моральної свідомості, що відображені в лексичній семантиці аксіономенів, характеризуючи почуття приязні, доброзичливості до батька або матері, дитини, друга (love ${ }_{17}$ : "a feeling of warm personal attachment or deep affection, as for a parent, child, or friend"), жалість, співчуття (mercy 10 : "the feeling that motivates compassion"), співчуття до тих, хто бідує або попав у немилість (charity 9 : "benevolent feeling, especially toward those in need бidувати or in disfavour"), скромність (humility 8 : "a humble feeling"), глибоку повагу, що грунтується на визнанні чиїхось видатних здібностей або досягнень (respect 8 : "a feeling of deep deference for someone elicited by their abilities, or achievements"), почуття приязні, викликане дружніми стосунками (friendship 6 , kindness: "friendly feeling") й обов'язком (loyalty: "feeling of duty"), щирі почуття (sincerity 4 : “an earnest and sincere feeling"), сильні почуття любові, поваги й обов'язку до своєї країни (patriotism 2 : “strong feelings of love, respect, and duty toward your country"), почуття подяки (gratitude 1 : "a feeling of thankfulness"); сумлінність (conscience 7 : "the conscientious feeling").

ГС "agreement, conformity" хоча і має статус семи комбінованої функціональності, але в досліджуваному мовному матеріалі вона виявлена в лексичних значеннях лише полісемантичних аксіономенів i позначає моральний принцип визначення правильної поведінки (justice 10 : “conformity to the moral principle determining just conduct"), уклад життя й поведінки встановленим морально-етичним принципам (virtue 9 : “conformity of one's life and conduct to moral and ethical principles") або визнаний стандарт пристойності (decency 5 : "conformity to the recognized standard of propriety"). 
Висновки 3 дослідження. Отже, провівши аналіз зазначених багатофункціональних, однофункціональних і ГС комбінованої функціональності в структурі українських та англійських аксіономенів, які безпосередньо торкаються моральнісної сфери буття людини, відмітимо, що вони своїми морально-етичними характеристиками нюансують моральну свідомість і моральну практику суб'єкта. Моральна свідомість семантизується вказівками на почуття шани, визначні риси та властивості людини, її світогляд. Показниками моральної практики в лексичних значеннях українсько- та англомовних аксіономенів виступають форми соціальної взаємодії як орієнтації на аксіологічно симетричні відношення між суб'єктами через констатацію доброзичливого ставлення один до одного. Діалектичний характер взаємодії моральної свідомості моральної практики визначається їхньою взаємною обумовленістю, нерозривною єдністю.

Перспективи подальших досліджень у цьому напрямі ми вбачаємо в зіставно-типологічному аналізі мовної об'єктивації аксіологічних категорій духовної культури українського, англійського та французького народів.

\section{ЛІТЕРАТУРА}

1. Етика : Навч. посібник. Київ : Либідь, 1992. 328 с.

2. Кондрашов В. А. Этика. Ростов-на-Дону : Изд-во «Феникс», 1988. 512 с.

3. Малахов В. А. Етика : курс лекцій : навч. посібник. [3-те вид.]. Київ: Либідь, 2001. 384 с.

4. Некрасова Н. А. Тематический философский словарь : учебное пособие. Москва : МГУ ПС (МИИТ), 2008. 164 с. Режим доступу : http://terme.ru/dictionary/907/symbol/204/page/2

5. Соколовская Ж. П. Система в лексической семантике (анализ семантической структуры слова). Київ : Вища школа, 1979. 189 с.

6. Селіванова О. О. Сучасна лінгвістика : напрями та проблеми. Полтава : Довкілля - К., 2008. 712 с.

7. Сорока Т. В. Семантика найбільш багатозначних англійських аксіономенів. Сучасні дослідження з іноземної філології. Ужгород, 2014. Вип. 12. С. 189-200.

8. Сорока Т. В. Семантична структура англійських аксіономенів із середнім ступенем полісемії. Науковий вісник Міжнародного гуманітарного університету. Серія «Філологія». Одеса, 2014. Вип. 11. T. 2. C. 64-67.

9. Сорока Т. В. Семантична характеристика аксіономенних спільностей (на матеріалі сучасної англійської мови). Мова і культура. Київ. 2014. Вип. 17. Т. II (170). С. 288-296.

10. Фабіан М. П. Семантика мовного етикету : новий підхід до її вивчення. Сучасні дослідження з іноземної філології. Ужгород, 2014. Вип. 12. С. 7-13. 
11. Фабіан М. Особливості семного складу етикетних слів української, англійської та угорської мов. Записки з романо-германської філології. 1999. Випуск 5. С.187-190.

12. Fabian M. Lexico-semantic Analysis of the Nouns Denoting Respect in English and Ukrainian. English versus Slavic. Lexicon in a Morphological and Semantic Perspective. 2017. Volume 5. P. 63-88.

13. Словник української мови : у 11-ти т. / [І. К. Білодід та ін.]. - К. : Наукова думка, 1970 - 1980. - Т. 1 - 11.

14. Oxford English Dictionary / Being a corrected re-issue with an introduction, supplement and bibliography of a new English dictionary on historical principles / Ed. by: J. A. H. Murray : Vol. 1-12. - Oxford : the Clarendon Press, 1970.

УДК 811.124'38+81-2: 808.51Лівій

DOI: $10.24144 / 2617-3921.2020 .18 .178-186$

Емілія Швед

кандидат філологічних наук, дочент, завідувачка кафедри класичної та румунської філології ДВНЗ «Ужсгородський наџіональний університет» orcid.org/0000-0002-9477-7579

м. Ужгород, Україна, тел.0956953050,emilija.shwed@uzhnu.edu.иа

Оксана Дацьо старший викладач кафедри класичної та румунської філології ДВНЗ «Ужсгородський національний університет» orcid.org/0000-0001-6974-9544 м. Ужгород, Україна, тел.0508229204, oksana.datio@uzhnи.еdu.иа

\section{Лінгвістичні особливості промов історичних осіб твору Т. Лівія «Історія» (на матеріалі промов I-ї декади твору)}

Анотація. Стаття присвячена вивченню власне лінгвістичної сторони стилю промов історичних осіб твору Т. Лівія «Історія». У колах науковиів існують суперечливі думки щодо специифіки мови автора «Історії». Одні дослідники схильні вважати, що мова промов тяжіє до класичної, інші ж зараховували Лівія до «срібної» епохи. Ми поставили за мету дослідити окремі аспекти мови та стилю промов першої декади «Історії», а саме їх власне лінгвістичну сторону, - лінгвістичні особливості промов. У науковій літературі відсутнє комплексне наукове вивчення цієї проблеми. 